DOI 10.18551/rjoas.2021-11.16

\title{
EMPIRICAL STUDY OF THE INFLUENCE OF BOARD OF DIRECTORS' FEATURE ON FIRM PERFORMANCE
}

Tariq Tawfeeq Yousif Alabdullah*

College of Administration and Economics, Department of Accounting, University of Basrah, Iraq

\author{
Iman Al-Fakhri
}

Faculty of Business and Finance, Department of Marketing, American University of Madaba, Jordan

Essia Ries Ahmed

Ahmed College of Economics, Management and Information Systems, University of Nizwa, Oman

Abdulkarim Kanaan-Jebna

School of Information and Communication Technology, Universiti Tunku Abdul Rahman, Malaysia

*E-mail: tariqtariq1984@gmail.com

\begin{abstract}
Earlier research on corporate governance, which includes board size as one of its major components, and business performance has expanded substantially in the last three decades. In this research, we analyze several studies that have been published between 2013 and 2021 to give a clear picture of the relationship. Furthermore, a brief review of the previous studies that have been done in several countries are introduced. We indicated that the number of publications that meet our search parameters had risen gradually over time, peaking in 2013 and other years. We identified two key types called (1) board size and firm performance as well as (2) CEO duality. We see a shift away from theoretical ideas, for instance, 'responsibility,' 'society,' and 'morals,' and toward increasingly concrete and workable phrases like 'CEO duality' and board size. Our research reveals that the study on firm performance and corporate governance is shifting from a theoretical strategy towards a more tactical and operational strategy.
\end{abstract}

\section{KEY WORDS}

Board of directors, firm performance, accounting, economics.

From accounting and economic perspective, the goal of this study is to see if good corporate governance (CG) has an impact on the performance of financial companies in the Middle East. Alabdullah et al. (2014a), explain the meaning of CG as all the factors affecting the institutional process, involving the pointing to the regulators or the controllers, included in organizing the services or/ production. According to Alabdullah (2021), CG is dealing with structures and processes via members who desire the company to take active measures to save all interested parties. CG has become a core element in contemporary trends as firms can grow and expand both in developing and developed economies (Alabdullah et al., 2016). As firms can be expanded, they might be able to use local and raw materials, sell to society, paying taxes, which could be useful to the society. Furthermore, modern companies' scandals have been blamed for not using and applying good CG. Firms' failures are huge, and this is such a big problem in the business world. For example, capital might be wiped out suddenly, and job losses might occur (Alabdullah et al., 2020). Nevertheless, it is important to mention that shareholders might strongly affect the company because if some of them are 
not satisfied with the work trend of the company, this will have a negative impact on this company.

Some companies make some changes in the principles and mechanisms of corporate governance by focusing on social issues and prioritizing them, thus changing the so-called usual governance and departing from focusing on shareholders and out of the idea of focusing only on maximizing the profits and interests of shareholders (Rodriguez-Fernandez, 2016). Therefore, there is evidence indicating that investors are interested in investing in companies with good governance, so they are ready to pay high premiums to buy the shares of these companies (Clark, 2007). This is the rationale for the association involving corporate governance methods and foundations and company performance, as well as the attention in research into this correlation in the research in this area (See., Alabdullah and Eny, 2021; Ahmed et al., 2016; Alabdullah et al., 2014; Alabdullah, 2018; Alabdullah et al, 2019; Alabdullah et al, 2020; Alabdullah et al, 2020; Abushammala et al, 2015; Alabdullah, 2020; Ahmed et al., 2021).Various researches have been conducted in recent years to investigate and examine the association involving financial performance and corporate governance. The majority of these research findings show that excellent corporate governance improves a company's performance. (Ahmed et al., 2014; Alabdullah et al, 2018; Ahmed et al., 2019; Alabdullah, 2016a; Alabdullah et al, 2014a). Contrarily, other studies have had a different opinion than the previous one (Alfadhl and Alabdullah, 2013; Alabdullah et al, 2018; Ahmed, 2014; Alabdullah et al, 2018; Alabdullah et al, 2014b; Ahmed et al., 2021; Ahmed et al., 2018; Alabdullah et al, 2016; Ahmed et al., 2020; Nor et al., 2020; Essia, 2014). Some other results in the literature review indicate that companies that adhere/and seek to improve corporate governance mechanisms are able to increase their value by more than $10 \%$ (Ahmed et al., 2020; Alabdullah, 2021a, 2021b; Alabdullah et al, 2021; Alabdullah, 2019; Ahmed et al., 2020). This is what the investor thinks about in researching companies that have a distinct and effective governance system. According to Alabdullah (2020), the results of some studies showed a positive relationship between the increase in borrowing loans from banks by some companies and the weakness of the corporate governance structure in those companies. The author mentioned that a large group of investors monitor the corporate governance system and whether its mechanisms are adhered to by companies. Since this is a positive indicator for investors, it is an important factor in encouraging them to invest in companies. For example, this includes the independence of managers in the board of directors and the lack of duplication of work between the CEO and the chairman of the board of directors, meaning that they are two separate people in these positions (Alabdullah, 2016a, 2016b, 2016c, 2016d; Khan et al., 2007; Uddin et al., 2018). A group of researchers, for example (Alabdullah et al, 2018; Alabdullah et al, 2014b; Khan et al., 2014, 2015), shows that the separation of shareholders from management creates difficulty because of this separation. This implies that the shareholders do not control and monitor the company. The agent represented by the managers prefers their personal interest over the interests of the owners (shareholders). Disputes and disagreements arise between managers and owners, and the so-called information asymmetry appears due to the incomplete contract between the two parties. They will find that their fiduciary duties are in stark contrast to their commercial interests. In the case of conflict of interest involving shareholders and managers, corporate governance assumes a crucial and effective role, according to Fama (1980). This is one of the characteristics of good corporate governance. Utilizing and applying principles and mechanisms of corporate governance play a fundamental role in managing differences of opinion and conflict of interests. Its role extends to what the agency theory sought to reduce agency costs and agency problems. In the past few years, there have been many collapses and financial crises, the most recent of which was the global economic crisis in 2008. Here, major American and European companies collapsed, including Enron and other giant companies. One of the mechanisms and principles that have been established under the concept of corporate governance. The handling and precaution with these crises raised the concerns of various parties, especially investors, in the decision-making process for them, as well as other important parties in societies such as consumers and employees. 
Therefore, the important thing is to investigate the studies that dealt with this matter and look forward to events based on management, accounting, economics, and financial theories.

\section{LITERATURE REVIEW}

When a corporate governance system (CGS) is effective, this will provide enhancement to the shareholders' trust because in doing so, it reflects that the firm is running in its best interests and wealth rather than in the interests and wealth of the top directors in the firm. CGS is a process that gives direction and control to the company. If completely applied, it helps management in the company do its best to reach the objectives that serve the shareholders' best interests and subsequently improve the firm's financial position. Others emphasize that the aim of CGS should not be just for enhancing the interest of the shareholders but further to enhance the interests of the stockholders such as suppliers, creditors, employees, and the societies. Unfortunately, history has shown repeatedly that managers, especially senior managers, are unscrupulous, as some of them abuse their power in fraud cases and thus negatively affect stakeholders. This fact became clear in 2001 when the year witnessed the fall of many companies, including Enron, and many scandals emerged at that time in many major companies. These scandals, fraud, and abuse are represented by companies using their money at the highest levels - CFOs and CEOs included. At that time, many questions arose about the strength and efficiency of the corporate governance system. At the time, the US Congress passed very important things, including the reform of corporate governance through the Sarbanes-Oxley Act of 2002.

A company's board of directors ought to have a number of members not below three and not exceeding fifteen, as decided by the company's memorandum of association, under the Corporate Governance Code for companies listed on The Amman Exchange (Amman Stock Exchange, 2009).

A large amount of financial and organizational economics literature acknowledges that board size has a significant impact on firm performance and effectiveness. (Rahim et al., 2018; Singh et al, 2019; Khan et al., 2014; Uddin al., 2020; Rahman et al., 2008; Jahur et al., 2014; ), as one of the most successful corporate governance systems for monitoring the firm's business, lowering agency costs, and improving firm performance (Thottoli et al., 2019a; Khan et al., 2012a; Uddin et al,. 2014 ). Nevertheless, past research on the influence of board of directors' size on firm performance has produced a wide range of results. According to certain research, the bigger the board of directors, the more productive and useful it is (Thottoli et al., 2019b). According to this research, the board of directors plays an essential part in directing and maintaining the company and, as a result, improving firm performance. Thottoli et al., (2019a) stated that a larger board size implies a greater diversity of perspective in the firm, which decreases agency costs and improves firm performance.. Alabdullah. (2019), who recognized that the agency's huge size causes it to be more observant about concerns because the board of directors has a larger number of members, and will be scrutinizing management's conduct.

Numerous past research has claimed that the outcomes are varied. For example, some show that a large board is necessary, while others concede that a small board is effective and results in improved firm performance. According to prior management and accounting research, a big board of directors is associated with effective performance (Alandullah and Eny, 2021). For instance, Samuel (2013) highlights that large board size has an effect on the financial performance of a firm. He discovers that a larger firm's financial performance is harmed by its size. (Alabdullah et al., 2019) acknowledge that when the board of directors grows in size, it will have a negative impact on the board of directors due to the absence of interaction and judgment calls between its members.

Traditional governance determinants such as small board size and company value, on the other side, have a favorable association, according to Yermack (1996). Similar research has backed up Yermack's findings (Alabdullah et al., 2019). Nonetheless, some past research claims that the size of the board of directors has little bearing on the firm's performance. For example, according to Connelly et al. (2012), there is no statistically 
relevant link between board size and Tobin's q. In a similar theme, Topak (2011) shows that there is no association connecting board size and firm performance. However, Andres and Vallelado (2008) demonstrate that there is an inverted U-shaped connection involving board size and performance.

The board of directors is one of the most important and distinctive aspects of both board dynamics as well as the general performance of corporate governance practices that supervise the company's business actions in order to guarantee that their agents appropriately handle it and to lower agency costs (Falih et al., 2021; Alabdullah et al., 2021a,b). Earlier researches agree that the efficacy of the board of directors can be determined by the level of experience and skills (Ahmed et al., 2020; Alabdullah et al., $2014 a, b)$. The outcomes of earlier research on the board of directors' performance revealed multiple ranges of opinions. Several of them believe that the bigger the board of directors, the more efficient, experienced, knowledgeable, and capable it is, and hence the superior the performance (Abushammala et al.,2015; Hashim et al., 2019; Rahim et al, 2018, 2019; Singh et al., 2019; Thottoli et al., 2019a,b,c). Other opinions in prior studies, on the other side, show that a small board of directors can produce an enhanced and more specific conclusion than a bigger one. According to this opinion, a smaller board of directors is more successful than a bigger board in terms of boosting cooperation and interaction. Furthermore, it may result in a reduction in a terrible decision by a substantial segment of the board (see Alfadhl and Alabdullah, 2016; Alabdullah et al, 2019). Meanwhile, others (Alabdullah \& Ahmed, 2020; Khan et al., 2010; Alabdullah \& Ahmed, 2019) demonstrate that there is no connection. Moreover, some scholars also (Ahmed et al., 2017; Ahmed et al., 2018) contend that the size of a company's board of directors has no bearing on its financial performance.

On the contrary, other researches (Alabdullah \& Ahmed, 2018; Ahmed et al., 2019) contended that a large board of directors is among the most crucial corporate governance tools that result in effective performance. Furthermore, several prior kinds of research findings in developed countries (Berger et al., 1997), others in developing nations, for instance (Alabdullah, 2019), and more recently, a research conducted by Alabdullah et al. (2016) and Alabdullah (2017), as well as other perspectives by Ahmed et al. (2019) and Alabdullah (2015), concede that there exists a poor association for both financial leverage and board size. Apart from that, Jamel et al. (2021) assessed the effects of agent-owner conflicts on Saudi firm performance. They discovered that such factors help Saudi firms perform better.

\section{H1. There is a negative association between the board of directors and firm} performance.

As per Jordanian Code of Corporate Governance (Amman Stock Exchange, 2009), at least one-third of a company's board of directors shall be non-executive/independent individuals. Furthermore, if the outcome of the above-mentioned third calculation is a fraction, the portion is eliminated by sending the value to the subsequent figure. The nonexecutive directors' presence on the board has been stated in the literature to have a favorable influence on easing and lowering agency costs. However, some prior research looked into the link between an independent board and business performance (Ahmed et al., 2014; Alabdullah, 2017), and the findings were irregular.

According to the findings of certain research, a board of directors with a large number of outsiders (non-executives) guarantees that the board oversees activity and improves firm performance (Ahmed et al., 2021).It highlighted that in the corporate governance sector, expanding the number of independent board members results in improved firm performance. Alabdullah, et al. (2016) discover a statistically significant and positive connection between board independence and Tobin's q, while one researcher's group uncovers that nonexecutives on the board of directors have no positive impact on firm performance (Alabdullah et al, 2021; Alyaarubi et al., 2021; Alsulmani et al., 2021; Ahmed et al., 2020). For example, Yermack (1996) shows that a large ratio of independent board members has a detrimental impact on firm performance.

H2: There is a positive association between board independence and firm performance. 


\section{METHODS OF RESEARCH}

As a cross-sectional study, this research included 80 firms listed in ASE for the year 2019. The data was then subjected to a quantitative analysis using the SPSS regression approach. Accounting data were gathered for all dependent and independent variables in the current project. We used corporate governance systems, board of director size, and managers' independence as independent variables, and return on assets (ROA) represents variables for the dependent variable to indicate firm performance.

\section{RESULTS AND DISCUSSION}

Multiple regression was utilized in this study to identify the clear association between the dependent variable and the independent variables. The tolerance for the independent variables in the present research was 0.712 for board size and 0.775 for managers' independence, as shown in Table 1. This implies that there is no concern with multicollinearity because the tolerance value of all the independent variables is greater than 0.1 . According to the data, the $R$ square value 0.895 for growth is displayed in Table 2 . This means that on the dependent variable, ROA, this number explains roughly $90 \%$ of the independent variables (managers' independence, board size).

Table 1 - Multicollinearity analysis

\begin{tabular}{lll}
\hline Variables & Tolerance & VIF \\
\hline Board size & 0.712 & 1.255 \\
Managers independency & 0.775 & 1.144 \\
\hline
\end{tabular}

Table 2 - R Square of Return on Assets

\begin{tabular}{ll}
\hline Model & ROA \\
\hline R Square & 0.895 \\
Sig F Change & .000 \\
\hline
\end{tabular}

Following the multiple regression analysis, as shown in Table 3, the correlation between firm performance and board of director size as measured by company return on assets $(R O A)$ was negative $(\beta=-.855)$, whereas the link between managers' independence and profitability was positive $(\beta=.133)$.

Table 3 - Regression analysis

\begin{tabular}{lll}
\hline ROA & Stand. Coefficient & \\
\hline Variables & Beta & Sig. \\
Board size & $-0.855^{\star \star *}$ & 0.000 \\
Managers independency & 0.133 & 0.526 \\
\hline
\end{tabular}

Note: Sig. ${ }^{*} p<.10,{ }^{* *} p<.05 \ldots{ }^{* * *} p<.01$.

The outcomes of this study's research assumptions concerning the relationship between the dependent variable and the independent variables were unexpected. At $\mathrm{P}<$ $0.00, \beta=-.855$, there is a strong negative and significant relationship between the board of directors' size and firm performance. That is to say that when the board of directors is limited, the profits are large. This result is supported by some of the research included in the literature review, for instance (Alabdullah et al., 2021).

As a result, $\mathrm{H} 1$ is deemed as a substantiated assumption, and the results indicate that small board sizes are prevalent among Jordanian publicly traded corporations. As a consequence of this finding, it appears that in Jordanian non-financial enterprises, a small board is a favorable circumstance for increasing firm profitability. Thus, the size of the board has a significant influence on firm profitability.

According to hypothesis two (H2), there is a positive relationship between firm performance and manager independence, as suggested by the present investigation. This 
element is not a concern with the company listed on the Amman Stock Exchange, which is the most likely explanation for such results. This represents the idea that managerial independence may or may not be beneficial in this situation. Risk management is projected to have a favorable impact on firm profitability, according to this study. $P>0.1, \beta=.133$ shows that the results are negligible.

\section{CONCLUSION}

The globalization and financial crisis and the rapid technology changes in light of manipulation and fraud have called for the need for transformation from traditional methods to contemporary ones in measuring firm performance. In order to restore and combat the paucity of firm performance measurement, it is critical to reflect and commit to the practice of firm performance measurement. Despite the fact that a large amount of research had evaluated firm financial performance in the literary works, the significant proportion was arguably predicated on the connection involving firm performance and measurement board feature in broad, with little attention paid to the possibility for tampering by the administration through a variety of behaviors.

\section{REFERENCES}

1. Abushammala, S. N., Alabdullah, T. T. Y., \& Ahmed, E. R. (2015). Causal Relationship between Market Growth and Economic Growth. Comparison Study. European Journal of Business and Management 7(33).

2. Ahmed, E. R., Alabdullah, T. T. Y., Ardhani, L., \& Putri, E. (2021). The Inventory Control System's Weaknesses Based on the Accounting Postgraduate Students' Perspectives. Journal of Accounting and Business Education, 5(2), 1-8. DOI: http://dx.doi.org/10.26675/jabe.v5i2.19312.

3. Ahmed, E. R., Islam, M. A., Alabdullah, T. T. Y., and bin Amran, A. (2018c). Proposed the pricing model as an alternative Islamic benchmark. Benchmarking: An International Journal 25, 2892-2912. doi: 10.1108/bij-04-2017-0077.

4. Ahmed, E. R., Alabdullah, T. T. Y., Shaharudin, M. S., \& Putri, E. (2020). Further Evidence on the Link between Firm's Control Mechanisms and Firm Financial Performance: Sultanate of Oman. Journal of Governance and Integrity, 4(1), 1-6.

5. Ahmed, E. R., Alabdullah, T. Y., Islam, M. A., \& Asmar, M. (2014) "Sukuk Legitimacy: A New Measurement Based on Content Analysis" 16th Malaysian Finance Association Conference in Sasana Kijang Central Bank of Malaysia, Kuala Lumpur, June 4-6, 2014.

6. Ahmed, E. R., Alabdullah, T. T. Y., Thottoli, M. M., \& Maryanti, E. (2020). Does Corporate Governance Predict Firm Profitability? An Empirical Study in Oman. The International Journal of Accounting and Business Society, 28(1), 127-143.

7. Ahmed, E. R., Aiffin, K. H. B., Alabdullah, T. T. Y., \& Zuqebah, A. (2016). Zakat and Accounting Valuation Model. Journal of Reviews on Global Economics, 5, 16-24.

8. Ahmed, E. R., Islam, M. A., and \&amp; Alabdullah, T. T. Y. (2017). The moderating role of Shariah supervisory board on sukuk pricing benchmark. International Journal of Excellence in Islamic Banking and Finance 6.

9. Ahmed, E. R., Islam, A., Zuqibeh, A., \& Alabdullah, T. T. Y. (2014). Risks management in Islamic financial instruments. Advances in Environmental Biology, 402-406.

10. Ahmed, E. R., Islam, M. A., Alabdullah, T. T. Y., \& Amran, A. B. (2019). A qualitative analysis on the determinants of legitimacy of sukuk. Journal of Islamic Accounting and Business Research, Vol. 10 No. 3, pp. 342-368.

11. Ahmed, E. R., Alabdullah, T. T. Y \& Shaharudin, M. S. (2020). Approaches to Control Mechanisms and Their Implications for Companies' Profitability: a Study in UAE. Journal of accounting Science, Vol. 4, no. 2, pp. 11-20.

12. Ahmed, E. R., Rahim, N. F. A., Alabdullah, T. T. Y., \& Thottoli, M. M. (2019). An examination of social media role in entrepreneurial intention among accounting students: a SEM study. Journal of Modern Accounting and Auditing, 15(12), 577-589. 
13. Ahmed, E. R., Alabdullah, T. T. Y., Amran, A., \& Yahya, S. B. (2018). Indebtedness Theory and Shariah Boards: A Theoretical Approach. Global Business and Management Research, 10(1), 127-134.

14. Ahmed, E. R., Islam, M. A., \& Alabdullah, T. T. Y. (2014). Islamic sukuk: Pricing mechanism and rating. Journal of Asian Scientific Research, 4(11), 640.

15. Alabdullah, T. T. Y. (2021). Management accounting insight via a new perspective on the risk management - companies' profitability relationship. International Journal of Intelligent Enterprise 7, in press.

16. Alabdullah, T. T. Y., Ahmed, E. R., and Nor, M. I. (2020). The World Declining Economy And Coronavirus Pandemic: Systems Should Be Continued. Russian Journal of Agricultural and Socio-Economic Sciences 102, 89-96. DOI: 10.18551/rjoas.2020-06.11.

17. Alabdullah, T. T. Y. (2021). Ownership Structure and the Failure or Success of Firm Performance: Evidence from Emerging Market; Cross-sectional Analysis. International Journal of Business and Management Invention, 10(8).

18. Alabdullah, T. T. Y. (2019). Management Accounting and Service Companies' Performance: Research in Emerging Economies, Australasian Accounting, Business and Finance Journal, 13(4), 100-118.doi:10.14453/aabfj.v13i4.8.

19. Alabdullah, T. T. Y. (2017). Compensation committee, company board attributes, and company performance: The moderating effect of leadership position. Paper presented at the 2017 Wei International Academic Conference Proceedings, July 24-27, 2017, Business and Economics.

20. Alabdullah, T. T. Y. (2016a). Are Board Size And Ownership Structure Beneficial In Emerging Markets' Firms? Evidence from Jordan. International Journal of Management \& Information Systems (IJMIS), 20(3), 87-94.

21. Alabdullah, T. T. Y. (2016d). Agency Theory Perspective: A Quantitative Study Of Accounting Performance Measures In Emerging Economies. ICTE Proceedings, New York.

22. Alabdullah, T. T. Y., Ahmed, E. R., \& Nor, M. I. (2018). New Ideas from Management, Finance and Accounting Perspective: The Research for A New Link Between A Company's Outcome and Risk Management. 5th International Conference on New Ideas in Management, Economics and Accounting.

23. Alabdullah, T. T. Y. (2016c). Corporate Governance from the Perspective of The Past and The Present and The Need to Fill an International Gap. Risk Governance \& Control: Financial Markets \& Institutions, 6(4).

24. Alabdullah, T. T. Y., Yahya, S., \& Ramayah, T. (2014b). Corporate Governance Development: New or Old Concept? European Journal of Business and Management, 6(7), 312-315.

25. Alabdullah, T. T. Y. (2016b). The Performance of Companies and The Board's Characteristics from the New Perspective of Manipulation Avoidance. Corporate Ownership \& Control, 13(4), 279-286.

26. Alabdullah, T. T. Y., Maryanti, E. (2021). Internal Control Mechanisms in Accounting, Management, and Economy: A review of the Literature and Suggestions of New Investigations. International Journal of Business and Management Invention, 10(9).

27. Alabdullah, T. T. Y., Ahmed, E. R. (2021). New Insights to Investigate the Impact of Internal Control Mechanisms on Firm Performance: A Study in Oman. Riset Akuntansi dan Keuangan Indonesia, Vol. 6(2).

28. Alabdullah, T. T. Y., Alfadhl, M. M. A., Yahya, S., \& Rabi, A. M. A. (2014). The Role of Forensic Accounting in Reducing Financial Corruption: A Study in Iraq. International Journal of Business and Management, 9 (1), 26.

29. Alabdullah, T. T. Y., Yahya, S., and Ramayah, T. (2014a). Corporate Governance Mechanisms and Jordanian Companies' Financial Performance. Asian Social Science 10, 247-247. DOI: 10.5539/ass.v10n22p247.

30. Alabdullah, T. T. Y., Ahmed, E. R., \& Ahmed, R. R. (2021). Organization features and profitability: Implications for a sample of Emerging Countries. Journal of Accounting and Business Education, 5(2), 43-52. DOI: http://dx.doi.org/10.26675/jabe.v5i2.16351. 
31. Alabdullah, T. T. Y., Ahmed, E. R., Mohammed Almashhadani, M, Yousif S, Almashhadani H, Almashhadani R, Putri, E (2021). How Significantly to Emerging Economies Benefit From Board Attributes and Risk Management in Enhancing Firm Profitability? Journal of Accounting Science 5(2).

32. Alabdullah, T. T. Y., Ahmed, E. R., (2020). A cross-sectional analysis of the influence of corporate governance features on the organizational outcomes: An assessment. International Islamic University Chittagong. 17(2), 6-26.

33. Alabdullah, T. T. Y., Yahya, S., Nor, M. I., \& Majeed, F. Q. (2016). An Investigation of Corporate Governance from a New Perspective: Examining the Financial Performance of Companies and the Impact of Executive Turnover. Corporate Board: Role, Duties \& Composition, 12(1).

34. Alabdullah, T. T. Y., Ahmed, E. R., \& Muneerali, M. (2019). Effect of Board Size and Duality on Corporate Social Responsibility: What has Improved in Corporate Governance in Asia?. Journal of Accounting Science, 3(2), 121-135.

35. Alabdullah, T. T. Y., Ahmed, E. R. (2019). Board Diversity and Disclosure of Corporate Social Responsibility Link: A Study in Malaysia. Journal of Adv Research in Dynamic \& Control System, 11(11).

36. Alabdullah, T. T. Y. (2018). The relationship between ownership structure and firm financial performance. Benchmarking: An International Journal, 25(1), 319-333.

37. Alabdullah, T. T. Y., Laadjal, A., Ries, E., \& Al-Asadi, Y. A. A. (2018). Board Features and Capital Structure in Emerging Markets. Journal of Advanced Management Science, 6 (2).

38. Alabdullah, T. T. Y., Nor, M. I., \& Ahmed, E. R. (2018). The determination of firm performance in emerging nations: Do board size and firm size matter? Management, 5(3), 57-66.

39. Alabdullah, T. T. Y., Ahmed, E. R., \& Nor, M. I. (2019). Do board characteristics provide more enhancement for firm financial performance? A corporate governance perspective. New challenges in corporate governance: Theory and practice (pp. 89-91). https://doi.org/10.22495/ncpr_25.

40. Alabdullah, T. T. Y \& Ahmed, E. R. (2020). Audit Committee Impact on Corporate Profitability in Oman Companies: an Auditing and Management Accounting Perspective. Riset Akuntansi dan Keuangan Indonesia, Vol. 5, no. 2, pp. 121-128.

41. Alabdullah, T. T. Y. and Ahmed, E. R. (2018). Corporate Governance: To What Extent it is important in the Arab Countries. International Journal of Science and Research 7.

42. Alabdullah, T. T. Y \& Ahmed, E. R. \& Abushammala, S. (2020). Growth of Companies: Empirical Study of the Companies Listed in Developing Economies. Journal of accounting Science, Vol. 4, no. 2, pp. 1-10.

43. Alfadhl, M. M. A. F. and Alabdullah, T. T. Y. (2013). Determinants of the Managerial Behavior of Agency Cost and Its Influential Extent on Performance: A Study in Iraq. International Journal of Humanities and Social Science, 3-3.

44. Alfadhl, M. M. A., Alabdullah, T. T. Y. (2016). Agency Cost and Management Behavior: The Role of Performance as a Moderator. International Journal of Science and Research (IJSR), 5(1), 1858-1864.

45. Almashhadani, M. (2021). How Dose Corporate Governance Leverage Organizational Performance: A Survey with Suggestions And Notes For Further Research. Russian Journal of Agricultural and Socio-Economic Sciences 3(111), 3-9.

46. Almashhadani, M. (2020). Testing the effecting elements of R\&D engineer's inventively in design industrialization Sector: A study in Singapore. Journal of Information and Computational Science, 10(5).

47. Andres, P. d., \& Vallelado, E. (2008). Corporate governance in banking: The role of the board of directors. Journal of Banking \& Finance, 32(12), 2570-2580. DOI: 10.1016/j.jbankfin.2008.05.008.

48. Alsulmani, A. H., Alkindi, S. S., \& Ahmed, E. R. (2021). Customer Accounting Information and Omani Service Companies' Performance. International Journal of Finance \& Banking Studies (2147-4486), 10(2), 79-88. 
49. Alyaarubi, H. J., Alkindi, D. S., \& Ahmed, E. R. (2021). Internal Auditing Quality and Earnings Management: Evidence from Sultanate of Oman. Journal of Governance and Integrity, 4(2), 115-124.

50. Essia Ries, A. (2014). Islamic Sukuk: Pricing mechanism and rating [Електронний pecypc]/Essia Ries Ahmed, Md. Aminul Islam, Tariq Tawfeeq Yousif Alabdullah. Journal of Asian Scientific Research, (4), 11.

51. Falih Chichan, H., \& Alabdullah, T. T. Y. (2021). Does Environmental Management Accounting Matter in Promoting Sustainable Development? A study in Iraq. Journal of Accounting Science, 5(2), 114-126.

52. Jahur, M. S., Quadir, S. M. N., \& Khan, M. A. (2014). Determinants of stock market performance in Bangladesh. Indonesian Management and Accounting Research, 13(1), 16-28.

53. Khan, M. A., \& Jahur, M. S. (2007). Human resource development practices in some selected business enterprises in Bangladesh: An explanatory study. Indonesian Management and Accounting Research, 6(1), 16-32.

54. Khan, M. A., \& Ali, A. J. (2014). The role of training in reducing poverty: the case of the ultra-poor in Bangladesh. International Journal of Training and Development, 18(4), 272 281. DOI: $10.1111 /$ ijtd.12041.

55. Khan, M. A., \& Ali, A. J. (2015). Do non-governmental organisations' socio-economic and training programmes improve disaster prevention capacity of their beneficiaries? International Social Work, 58(3), 401-420. DOI: 10.1177/0020872815570074

56. Khan, M. A., Ali, A. J., \& Arefeen, S. (2014). The impact of training on NGO beneficiaries' education in Bangladesh: The missing link. Advances in Environmental Biology, 8(9), 679-88.

57. Khan, M. A., \& Ali, A. J. (2012a). Factors affecting customers' intention towards online shopping in Bangladesh. Indonesian Management and Accounting Research, 11(1), 2136.

58. Khan, M. A., Toy, M. M., \& Siddique, A. (2010). Stimulating factors and justification of the strategic approach applicable for the internationalisation of SMEs in Bangladesh. Indonesian Management and Accounting Research, 9(2), 1-14.

59. Nor, M. I., Masron, T. A., \& Alabdullah, T. T. Y. (2020). Macroeconomic fundamentals and the exchange rate volatility: empirical evidence from Somalia. SAGE Open, 10(1), 2158244019898841.

60. Rahim, N. F. A., Ahmed, E. R., \& Faeeq, M. K. (2018). Internal Control System and Perceived Operational Risk Management in Malaysian Conventional Banking Industry. Global Business \& Management Research, 10(1).

61. Rahim, N. F. A., Ahmed, E. R., Sarkawi, M. N., Jaaffar, A. R., \& Shamsuddin, J. (2019). Operational risk management and customer complaints: the role of product complexity as a moderator. Benchmarking: An International Journal.

62. Rahman, M. O., \& Khan, M. A. (2008). Display unit for Bangla characters. IIUC Studies, 4, 71-86.

63. Samuel, A. (2013). „The impact of bigger board size on financial performance of firms: The Nigerian experience". Journal of Research in International Business and Management.

64. Singh, K. S. D., Islam, M. A., Ahmed, E. R., \& Amran, A. (2019). An empirical investigation into the major drivers of corporate social responsibility. Opción, 35, 10761090.

65. Thottoli, M. M., Thomas, K. V., \& Ahmed, E. R. (2019a). Examining the impact of information communication technology on auditing professionals: A quantitative study. Journal of Advanced Research in Dynamical and Control Systems, 11(12), 476-488.

66. Thottoli, M. M., Thomas, K. V., \& Ahmed, E. R. (2019b). Qualitative analysis on information communication technology and auditing practices of accounting professionals. Journal of Information and Computational Science, 9(9), 529-537.

67. Topak, I., T. (2011). The Effect of Board Size on Firm Performance: Evidence from Turkey. Middle Eastern Finance and Economics, (14), 119-127. 
68. Thottoli, M. M., Thomas, K. V., \& Ahmed, E. R. (2019c). Adoption of audit software by audit firms: a qualitative study. Journal of Information and Computational Science, 9(9), 768-776.

69. Uddin, M., Ali, K., \& Khan, M. A. (2018). Impact of service quality (SQ) on student satisfaction: empirical evidence in the higher education context of emerging economy. AL-'ABQARI: Journal of Islamic Social Sciences and Humanities, 16, 31-67.

70. Uddin, M., Ali, K., \& Khan, M. A. (2020). Perceived social support (PSS) and work-life balance in a developing country: The moderating impact of work-life policy. Iranian Journal of Management Studies, 13(4), 733-761.

71. Uddin, M. M., Khan, M. A., \& Farhana, N. (2014). Banking services and customer perception in some selected commercial banks in Bangladesh. Indonesian Management and Accounting Research, 13(1), 1-15.

72. Yermack, D. (1996). Higher market valuation of companies with a small board of directors. Journal of financial economics, 40(2), 185-211. 